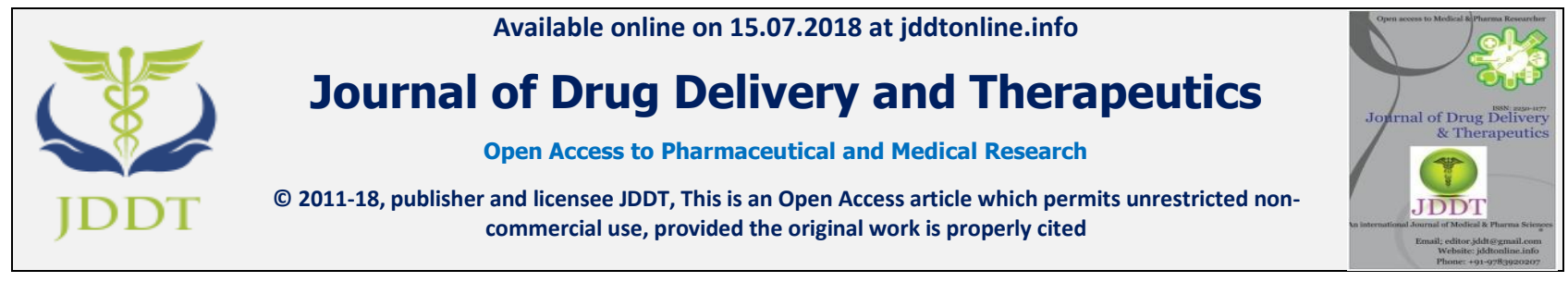

Open $\odot$ Access

Review Article

\title{
AYURVEDA REVIEW ON “DADIMASHTAKA CHURNA” AND ITS CLINICAL IMPORTANCE
}

\author{
Dr. Ranjit Narang ${ }^{1}$, Dr. Isha Herswani ${ }^{2}$ \\ ${ }^{1}$ Lecture, Dept. of Kaumarbhritya, Rani Dullaiya Smriti Ayurved P.G. College and Hospital, Bhopal, India \\ ${ }^{2}$ Ph.D. Scholar, Dept of Rachna Sharir, National Institute of Ayurveda, Jaipur, India
}

\begin{abstract}
Dadimashtaka Churna a polyherbal Ayurvedic formulation mainly used for gastro intestinal problem such as; diarrhea. Tawaksheeri, Twak, Patra, Ajamoda, Dhanyaka, Ajaji, Granthi, Pippali, Dadima and Sita are the main ingredients of formulation. Dadimashtaka churna prepared by mixing various herbs with sugar and traditionally it is recommended to take 3 to 5 grams of formulation with warm water/rice soup after meal. However it should be used cautionary with diabetic patients. The presence of various chemical constituents of different herbs makes this formulation worth full for gastric trouble especially digestive problems. The folklore use of Dadimashtaka churna needed to explore to enhance global acceptance of this formulation, considering this fact current article summarizes various aspect of Dadimashtaka churna.
\end{abstract}

Keywords: Ayurveda, Dadimashtaka Churna, Sita and Diarrhea.

Article Info: Received 03 June, 2018; Review Completed 11 July 2018; Accepted 13 July 2018; Available online 15 July 2018

口过回 Cite this article as:

Narang R, Herswani I, Ayurveda review on "Dadimashtaka Churna" and its clinical importance, Journal of Drug Delivery and Therapeutics. 2018; 8(4):80-82 DOI: http://dx.doi.org/10.22270/jddt.v8i4.1804

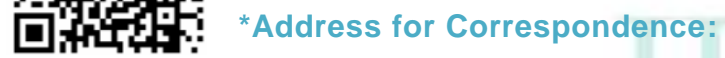

Dr. Ranjit Narang, Lecture, Dept. of Kaumarbhritya, Rani Dullaiya Smriti Ayurved P.G. College and Hospital, Bhopal, India

\section{INTRODUCTION}

The ancient text of India witnessed rich heritage of ayurveda science and it was believed traditionally that natural medicines may cure many of diseases and help to maintain normal health status. The global acceptance of natural medicine increases day by day due to their property to exert lesser side effects as compared to synthetic medicines. In last few decades the experimentally and rationally proved evidences also enhance world wide acceptance of natural remedies. The herbs, herbal formulation, traditional ayurveda formulations, animal products and metalic preparations used as natural remedies. The traditional ayurveda formulations prepared as per the method prescribed by ayurveda formulary. The Dadimashtaka Churna is one of the important ayurveda formulation used for intestinal problems such as; diarrhoea, indigestion, dysentery and loss of appetite. This article presented ayurveda perspective on Dadimashtaka Churna along with its clinical importance.
$>$ The ingredient of Dadimashtaka Churna balances Rasa-Panchaka and thus offers Deepana, Pachana and Vatanulomana properties.

> Doshprashamana propertiey of VataKapha shamaka pacify Amadosha.

$>$ Affect Jatharagni and thus relieve Grahani Dosha.

$>$ It offers Tridosha Shamaka especially Kapha-Vata Shamaka properties due to combination of Doshaghnata.

\section{Chemical composition:}

It contains about 14 ingredients and pomegranate (dadima) is chief ingredient of dadimashtaka churna. It contains carbohydrate, terpenoids, flavonoids and tannins. Calcium oxalate crystal of Punica grantum, Siliceous crystals due to the presence of Bambusa arundinacea and oil globules of Piper nigrum. It also consisted of camphene, geraneol, linalool, menthone, myrcene, saibenene, terpeneols, citral and sitosterol. The 
presence of essential oil and flavanoids also proved in formulation.

\section{Preparation of Dadimashtaka Churna}

The various herbs used for the preparation of Dadimashtaka Churna powder individually and fined by using sieve of 80 mesh size to obtain uniform size of powdered particle. The pulverized herbs weigh separately and mix together as per the specified quantity. This mixture of various herbs sieved again to get uniform composite mixture of various herbs. The final product in powder form pack and store in cool and dry place.

Table 1: The compositions of formulation (Dadimashtaka Churna)

\begin{tabular}{|c|l|c|c|l|c|}
\hline S. No. & Ingredient & Quantity & S. No. & Ingredient & Quantity \\
\hline 1 & Tawaksheeri & 1 Part & 8 & Ajaji & 2 Parts \\
\hline 2 & Twak & 2 Parts & 9 & Granthi & 2 Parts \\
\hline 3 & Patra & 2 Parts & 10 & Shunti & 2 Parts \\
\hline 4 & Ela & 2 Parts & 11 & maricha & 2 Parts \\
\hline 5 & Nagakesara & 2 Parts & 12 & Pippali & 2 Parts \\
\hline 6 & Ajamoda & 2 Parts & 13 & Dadima & 2 Parts \\
\hline 7 & Dhanyaka & 2 Parts & 14 & Sita & 16 Parts \\
\hline
\end{tabular}

\section{Properties of Dadimashtaka churna:}

Roga karma: Athisara, grahani, ajeerna, agnimandya, arochaka.

Dosha karma: Tridoshahara

Agni karma: Deepana

Gunas:

Grahi

Rasa:

Katu and Tikta.

Virya: Ushna

Vipaka: Katu and Madhura.

\section{Medicinal uses of Dadimashtaka churna}

- Improves metabolic process

- $\quad$ Promote appetite

- Reduces intestinal infection

- Act as an internal antimicrobial agent

- Help in the management of loose motion and grahani

- Control irritable bowel syndrome

Table 2: The Panchak properties (Rasa and Vipak) of various ingredients of Dadimashtaka churna:

\begin{tabular}{|l|l|l|}
\hline Name of ingredient & Ras & Vipak \\
\hline Tawaksheeri & Kashay, Madhur & Madhur \\
\hline Twak & Katu, Tikt & Katu \\
\hline Patra & Katu, Tikt & Katu \\
\hline Ela & Katu, Madhur & Madhur \\
\hline Nagakesara & Kashay, Tikt & Katu \\
\hline Ajamoda & Katu, Tikt & Katu \\
\hline Dhanyaka & Kashay, Tikt, Katu, Madhur & Madhur \\
\hline Ajaji & Katu & Katu \\
\hline Granthi & Katu & Madhur \\
\hline Shunti & Katu & Madhur \\
\hline Maricha & Katu & Katu \\
\hline Pippali & Katu & Madhur \\
\hline Dadima & Kashay, Amla, Madhur & Madhur/Amla \\
\hline Sita & Madhur & Madhur \\
\hline
\end{tabular}

Role of Dadimashtaka Churna in Intestinal Disease (Grahani Dosha):

- Dadimashtaka Churna pacify Agni, regulates Jatharagni. Its Katu and Tikta Rasa pacify vitiated Kapha while Ushna Virya of formulation pacifies Vata Dosha.
- $\quad$ Tikshna Guna and Ushna Virya stimulate the Agni thus boost appetite.

- Formulation also pacifies Vayu and Akasha Mahabhuta which stimulates all types of Agni.

- It opens up Sroto avrodha due to its properties such as; Laghu, Ruksha, Tikshna Guna and Ushna Virya. 
- The removal of Sroto avrodha stimulates Sapta Dhatwagnis.

- Katu Vipaka and Ushna Virya of formulation offer Ama-nashaka and Laghutwa properties which maintain normal state of Sama Rasa Dhatu and equilibrium of Rasa Raktadi Dhatus.

- It possesses Amapachaka property and reduces colonic motility thus helps to manage Muhurdrava Mala Pravriti.

- It helps in absorption of food, acts as Aruchinashaka and Kaphanashaka agent.

- Dadimashtaka Churna boosts Trishna pacify Agni dushti and control effect of Ardhpakwa Anna and prakupita Pitta since it possess Trishnashamaka and Anupana quality.

- Aruchinashaka property of the ingredients of formulation offer relief in Arochaka.

- Pitta shamaka property of Dadimashtaka Churna relieves Mukha Vairasya.

- Pacification of Agnimandya and Ama remove formation of bad purisha.

- Agni vraddhikara and Vata Kapha hara property of formulation prevent mucous in mala.

- Dadimashtaka Churna Dadima \& Sita offer balya properties thus strengthen Dhatu and metabolic activities.

\section{REFERENCES}

1. Tiwari PV, Kashyapa Samhita (Vriddha Jeevakeeya Tantra), text with English Translation and Commentary, Chaukhambha Vishvabharati, Varanasi, Reprint ed. 2013.

2. Gupta KA, Ashtanga Hridayam of Vagbhatta; With the Vidyotini Hindi commentary; edited by Y. N. Upadhyaya; Choukhamba Sanskrit Sansthan, Varanasi (India) ed. 2011.

3. Shastri AD, Sushrut Samhita - Ayurved tattva Sandeepika with hindi commentary and Hindi Translation of Sanskrit introduction, Chaukhambha Sanskrit Sansthan Varanasi, Reprint ed. 2011

4. Sharangadhara Samhita by Pandit Sharangadharacharya Son of Pandit Damodara with the Commentary Adjamalla's by Chaukhambha Orientalia, Varanasi, $5^{\text {th }}$ edition 2002.

5. Saxena N, Yogaratnakara, Choukhamba Orieantalia, Varanasi (India) Vol I II Edition 2003.
- Katu Tikta Rasa and laghu guna of formulation offer samprapti bhanga effect in Grahani Dosha thus reduces symptoms of intestinal problesm such as; Alasya.

\section{CONCLUSION}

Dadimashtaka Churna is described by Acharya Govind das sen; Bhaishajya Ratnawali in Grahani Rogadhikara. Dadimashtaka Churna with Koshna Jala as Anupana offer Laghu, Ruksha, Tikshna Guna, Katu, Tikta Rasa, Katu Vipaka, Ushna Virya and Deepana, Pachana properties, these all properties of formulation helps in the management of intestinal disease such as; Grahani Dosha. Dadimashtaka Churna helps to pacify Muhurbaddh Muhurdravam mala pravritti, Alasya, Trishna, Balakshaya, Arochaka and Mukha Vairasya. Dadimashtaka Churna controls Doshic properties such as; Kledaka Kapha, Pachaka Pita and Samana Vayu. Dadimashtaka Churna improves Agni at various stages; Pachana-Avastha Paka (Madhura, Amla, Katu awastha paka) Vipaka. The literature study revealed that Dadimashtaka Churna is very good formulation for the management of diarrhea, dysentery, indigestion and irritable bowel syndrome.

6. Bhishagratn Pt. Shri Bramh Shankar Mishr, Bhav Prakash, Vidhyotini Hindi Vyakhya, Chaukhambha Sanskrit Sansthan,Varanasi(India) Edition 1997.

7. Pt. Hariprasad Tripathi, Hareet Samhita, Chaukhambha Krishndas Academy, Varanasi (India), Edition 2009.

8. Amarasinha, Amaroakosha, Ed. By Ramashrami: Rashtriya Samskrita Samsthan, New Delhi, 2003.

9. Mishra Siddhinandan, "Bhaishajya Ratnavali "Siddhiprada" Surbharti prakashan I edition.259.

10. Charaka Samhita; with the Ayurveda-Deepika Commentary of Chakra-Panidutta with Vidyotini Hindi Commentary of Pt. Kashinath Shastri, Part- I and II; Choukhamba Bharti Academy, Varanasi (India); Reprint ed. 2011. 